\title{
Revitalising Agriculture in Eastern India: Investment and Policy Priorities
}

\author{
Nilachala Acharya and Subrat Das
}

\begin{abstract}
This article examines the priority accorded to agriculture and allied sectors in India's public expenditure over the last two decades, with specific attention to budgetary spending by the eastern region states. It observes that one of the important reasons for the slowdown of growth in Indian agriculture seems to have been the stagnation in public expenditure on the overall rural economy (i.e. Agriculture and Allied Activities, Irrigation and Flood Control, Village and Small Industries, Rural Development and Special Area Programmes) since the early 1990s. The falling priority given to the rural economy in the last three Five Year Plans of the country would have affected the eastern region states more adversely due to their weaker fiscal health and less developed agricultural sectors. The article also argues that there is a need to redesign the policy framework and provide adequate budgetary support for agricultural activities in dryland/rainfed areas in the eastern region states.
\end{abstract}

\begin{abstract}
1 Introduction
Public spending through budgets is widely recognised as one of the most direct and effective instruments that governments can use to promote desirable trajectories of development and there is enough evidence to suggest that public policies favouring adequate budgetary expenditures towards agriculture and rural development play a crucial role in shaping the overall growth of the economy while ensuring agricultural development and reducing the incidence of absolute poverty. Elaborate discussions on these issues can be found in Chand 2010; Vyas 2004, 2008; Patnaik 2003; Ramachandran and Swaminathan 2002; Fan et al. 2000; Bates 1997; Hayami and Ruttan 1985; and Pinstrup-Andersen et al. 1976, among others. As is well acknowledged by now, agriculture in developing countries has been experiencing serious difficulties in recent years, in large measure on account of policies rooted in neoliberal macro-economic frameworks (Jha and Acharya 2012; Ghosh 2010; Patnaik, U. 2006, 2007 and 2011; Patnaik, P. 2005; Amin 2004;

Ramachandran and Swaminathan 2003; and Jha 2002, among others). One major element of such policy regimes has been relative neglect of the rural areas in general and the agriculture sector in particular in terms of budgetary allocations and spending. Inadequate public provisioning and
\end{abstract}

state inaction can have serious adverse consequences for agricultural development and the wellbeing of the masses, as witnessed across the developing world in varying measures, and India is no exception to this general trend.

For a country like India, the importance of agriculture in facilitating decent livelihoods continues to be critical, given that a majority of the country's population depends primarily on this sector. Further, it is well documented that the performance of this sector since the early 1990s has been disappointing. The sector witnessed a growth rate of 4.8 per cent per annum during the 8th Five Year Plan (average for 1992-97), but a downturn in the 9th Five Year Plan (average of 2.5 per cent per annum during 1997-2002) and the 10th Five Year Plan (average of 2.4 per cent per annum during 2002-07). Even during the 11th Five Year Plan (2007-12), the average growth rate of the agriculture sector at 3.5 per cent per annum as compared to a much higher growth rate of 8.2 per cent per annum for the whole economy has been a cause for serious concern (Figure 1).

It has been widely observed that, over the last one and a half decades, agriculture in India has become unviable as an occupation with 


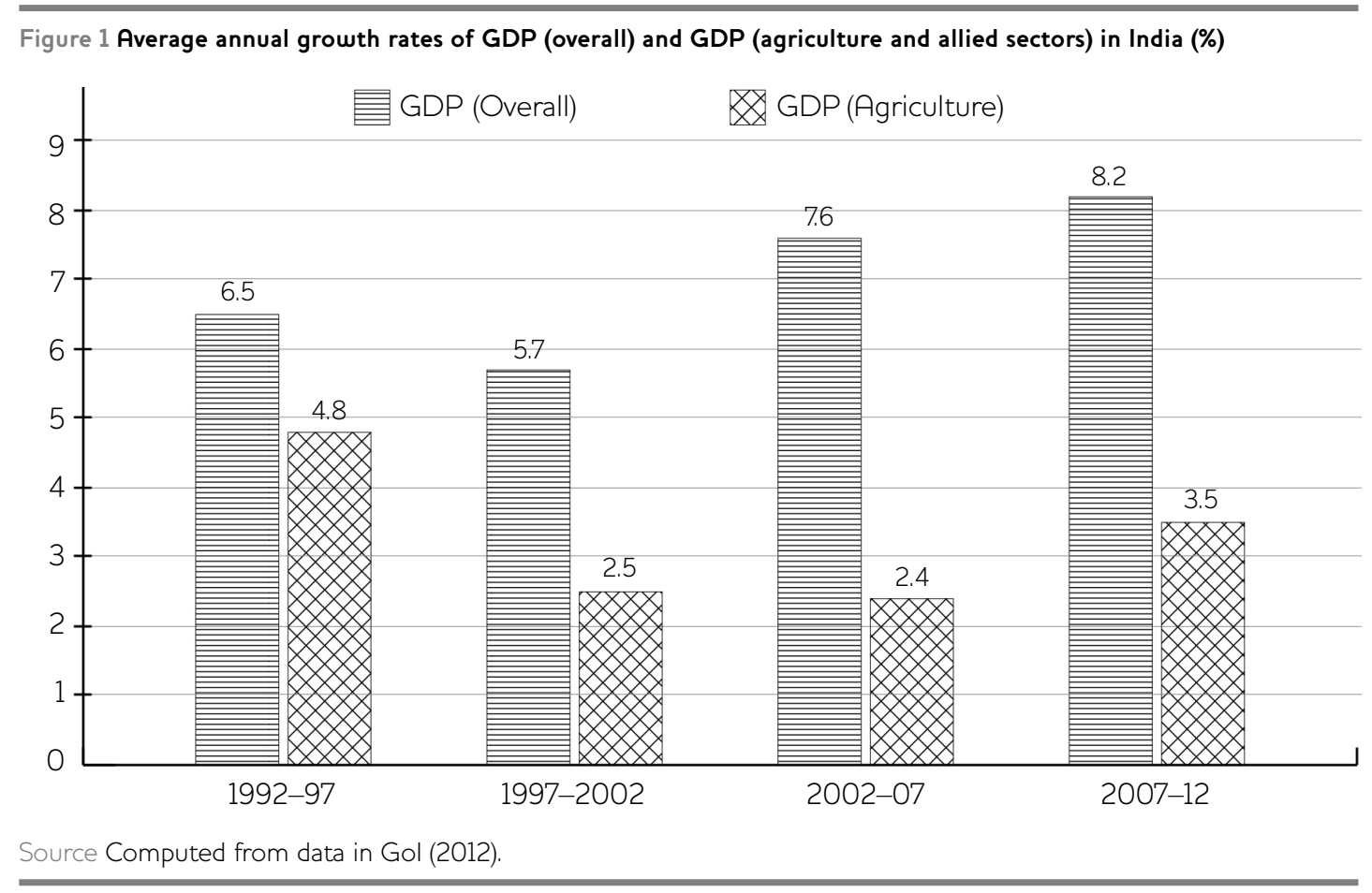

widespread distress, the most disturbing manifestation of which has been the suicides committed by a large number of farmers over this time period. Even though the contribution of the agriculture sector to the overall gross domestic product (GDP) of the country has fallen from about 29.6 per cent in 1990/91 to as low as 13.9 per cent in 2011/12, this sector still employs around 67.6 per cent of India's workforce (in 2009/10). Similarly, the per capita GDP of workers who are engaged in the agricultural sector is only about one-fifth of those employed in the non-agricultural occupations, and the gap between the two is continuously widening (for detailed accounts, see Sen 2003 and Bhalla 2007).

\section{Agricultural performance of the eastern region states}

The problems in the agriculture sector in India, however, are not uniform across the country. While the huge diversity of agro-climatic conditions in the country has influenced the agricultural performance of different regions and states, the skewed regional priorities in state support for agriculture have also played a major role in accentuating the disparity in agricultural performance of different regions. Some of the agricultural policy analysts have opined (for example, the views put forward by a coalition of policy analysts and civil society organisations in India, called the Revitalizing Rainfed Agriculture [RRA] network) that the statedirected policies relating to the Green Revolution have resulted in a situation in which any kind of state support for the agriculture sector becomes effective only when there is availability of water for agriculture. This kind of policy regime (focusing primarily on irrigated agriculture) has aggravated the problems of agriculture in the dryland/rainfed regions in the country. As a result, in a sizeable part of the country, agriculture has borne the brunt of nature very frequently, with almost every alternate year being recorded as a year of natural disaster with large-scale adverse impacts on agricultural production and productivity.

In order to look at the agricultural performance of the eastern region states over the last decade, it would be useful to take into account a couple of key indicators for the relevant states - Assam, Bihar, Chhattisgarh, Jharkhand, Orissa, Uttar Pradesh and West Bengal. A few other states have also been taken into account - those which have benefited from the state-directed policies relating to the Green Revolution (such as Punjab) or which have witnessed more progressive budgetary policies from the State 


\begin{tabular}{|c|c|c|c|c|c|c|c|}
\hline \multirow{2}{*}{ State } & $2005 / 06$ & $2006 / 07$ & $2007 / 08$ & $2008 / 09$ & $2009 / 10$ & $2010 / 11$ & \multirow{2}{*}{$\begin{array}{l}\text { Average annual } \\
\text { growth rate for } \\
2005 / 06-2010 / 11\end{array}$} \\
\hline & \multicolumn{5}{|c|}{ Annual growth rate of GSDP [at constant (2004/05) prices] } & & \\
\hline Andhra Pradesh & 6.1 & 2.0 & 17.4 & 1.8 & 1.1 & 9.1 & 6.2 \\
\hline Assam & 2.6 & 1.9 & 2.8 & 6.3 & 4.2 & 6.1 & 4.0 \\
\hline Bihar & -7.6 & 24.5 & -6.2 & 10.7 & -11.3 & 8.4 & 3.1 \\
\hline Chhattisgarh & 12.8 & 4.5 & 9.3 & -9.9 & 8.0 & 4.4 & 4.8 \\
\hline Jharkhand & 3.6 & 12.6 & 5.6 & 10.5 & 7.4 & 7.7 & 7.9 \\
\hline Orissa & 3.3 & 2.0 & 4.9 & 0.2 & 9.4 & 0.4 & 3.4 \\
\hline Punjab & 1.0 & 2.9 & 3.8 & 2.2 & 1.4 & 1.8 & 2.2 \\
\hline Tamil Nadu & 13.3 & 13.2 & -4.4 & -2.3 & 2.4 & 7.0 & 4.9 \\
\hline Uttar Pradesh & 2.3 & 2.4 & 3.5 & 3.3 & 0.3 & 5.2 & 2.8 \\
\hline West Bengal & 2.2 & 2.1 & 6.2 & -2.2 & 6.3 & NA & 2.9 \\
\hline All States and UTs & 5.1 & 4.4 & 5.5 & 0.6 & 1.8 & -18.3 & -0.2 \\
\hline
\end{tabular}

Governments for agriculture over recent decades (such as Tamil Nadu and Andhra Pradesh).

As shown in Table 1, during 2005/06 to 2010/11, the annual growth rate of Gross State Domestic Product (GSDP) from agriculture and allied sectors has been relatively higher for Jharkhand, Chhattisgarh and Assam; it has been lower for Bihar and Orissa; and it has been the lowest among the seven eastern region states for Uttar Pradesh and West Bengal. Among the other three states being taken into account, the rate of growth of GSDP from agriculture and allied sectors has been relatively higher for Andhra Pradesh and Tamil Nadu, while Punjab shows a much lower rate of growth during 2005/06 to 2010/11 (comparable with the low growth rates witnessed for Uttar Pradesh and West Bengal).

Table 2 presents a comparison of yield (in kilograms/hectare) of total foodgrains for the same set of states since 2000/01. The average yield of total foodgrains over the decade from 2000/01 to 2009/10 has been significantly higher for Punjab (at 3,784 kg/ha) which reflects the significant relative improvement in production of foodgrains in states like Punjab as a result of the Green Revolution policies since the late 1960s.
Three of the selected states - West Bengal (at 2,365 kg/ha), Andhra Pradesh (at 2,228 kg/ha) and Uttar Pradesh (at 2,168 kg/ha) - have registered average yield levels of total foodgrains that are way below the level attained by Punjab but much higher than the national average (at $1,774 \mathrm{~kg} / \mathrm{ha}$ ) over the period from 2000/01 to 2009/10. Among the remaining states (taken for comparison here), Chhattisgarh (at 1,011 kg/ha), Orissa (at 1,266 kg/ha), Jharkhand (at 1,345 $\mathrm{kg} / \mathrm{ha}$ ), Assam (at 1,450 kg/ha), and Bihar (at $1,553 \mathrm{~kg} / \mathrm{ha}$ ) have registered average yield levels of total foodgrains that are way below the national average for the last decade.

However, we may also note here that, in terms of the increase in the yield of total foodgrains between 2000/01 and 2009/10, Orissa and Chhattisgarh have shown the highest increases; followed by West Bengal, Jharkhand, Assam and Andhra Pradesh with moderate increases; Uttar Pradesh, Punjab and Tamil Nadu with much smaller increases; whereas Bihar shows a decline (from 1,694 to $1,530 \mathrm{~kg} / \mathrm{ha}$ ).

It has been argued by several economists that the stress experienced by Indian agriculture and the slowdown in its rate of growth over the last one 


\begin{tabular}{lcccc}
\hline Table 2 Yield (kilograms/hectare) of total foodgrains of select states in India since $\mathbf{2 0 0 0 / 0 1}$ \\
\hline States/years & $\mathbf{2 0 0 0 / 0 1}$ & $\mathbf{2 0 0 9 / 1 0}$ & $\begin{array}{c}\text { Average yield of } \\
\text { total foodgrains } \mathbf{( k g} / \mathbf{h a}) \\
\mathbf{( 2 0 0 0 / 0 1 - 2 0 0 9 / 1 0 )}\end{array}$ & $\begin{array}{c}\text { Variation of yield } \mathbf{( k g} / \mathbf{h a}) \\
\text { in total foodgrains } \\
\mathbf{2 0 0 0 / 0 1 - 2 0 0 9 / 1 0}\end{array}$ \\
\hline Andhra Pradesh & 2,089 & 2,294 & 2,228 & 205 \\
Assam & 1,457 & 1,662 & 1,450 & 205 \\
Bihar & 1,694 & 1,530 & 1,553 & -164 \\
Chhattisgarh & 589 & 1,008 & 1,011 & 419 \\
Jharkhand & 1,095 & 1,330 & 1,345 & 235 \\
Orissa & 1,397 & 1,266 & 447 \\
Punjab & 950 & 4,144 & 3,784 & 112 \\
Tamil Nadu & 4,032 & 2,477 & 1,972 & 16 \\
Uttar Pradesh & 2,461 & 2,236 & 2,168 & 291 \\
West Bengal & 2,231 & 2,522 & 2,365 & 172 \\
All India & 1,626 & 1,798 & 1,774 &
\end{tabular}

Source Compiled from Gol (2011c).

and a half decades is, in large measure, due to low priorities accorded to the agriculture and allied sectors in the budgets of both the Union and State Governments in the country over this period (for a discussion of trends in public expenditure in India since the early 1990s, see contributions in Jha 2011). Hence, it would be pertinent to examine the priorities accorded to agriculture and allied sectors in the Five Year Plans of the country over the last two decades and the trends in budgetary expenditures for agriculture and allied sectors in the selected states for the last few years. In the last couple of years, the Union Government has introduced a new programme in the eastern region states, which aims to address the problems confronted by these states in the agriculture sector in general and those pertaining to dryland/rainfed agriculture in particular. In this context, it would be worthwhile to also examine the budgetary expenditure by the Union Government on dryland/rainfed agriculture in the country.

\section{Priorities for budgetary expenditure in agriculture and allied sectors}

The ascendency and dominance of the neoliberal economic policy paradigm since the early 1990s has been a major factor underlying the agrarian crisis in the country. Factors like increased input prices, vulnerability to world market price fluctuations due to greater openness, inadequate/non-existent crop insurance and weakening of credit provision, along with the government's indifference to farmers' demand for remunerative prices for their farm produce and compression of public expenditures for agriculture and rural development are among the obvious causal factors underlying the contemporary agrarian crisis in the country. The point worth emphasising here is that of relative stagnation in public expenditure for the overall rural economy (in which we include the following broad heads of budgetary expenditure in India Agriculture and Allied Activities, Irrigation and Flood Control, Village and Small Industries, Rural Development, and Special Area Programmes) during the phase since the early 1990s. In the present analysis, we are taking into account a number of sectors pertaining to the rural economy along with the core agriculture sector since the activities/interventions covered by the agriculture sector, as defined in the country's budgetary classifications, do not include several important areas that are relevant to farmers and agriculture.

In the last two decades, one of the major consequences of the adoption of the neoliberal economic policy paradigm in India has been a gradual shrinking of the fiscal policy space for the 
Table 3 Share of plan expenditure towards the overall rural economy in India (\%)

\begin{tabular}{lcccccc}
\hline & \multicolumn{7}{c}{ Share of total plan expenditure in the country } \\
\cline { 2 - 6 } Plan periods & $\begin{array}{c}\text { Agriculture } \\
\text { and allied } \\
\text { activities }\end{array}$ & $\begin{array}{c}\text { Irrigation } \\
\text { and flood } \\
\text { control }\end{array}$ & $\begin{array}{c}\text { Village and } \\
\text { small } \\
\text { industries }\end{array}$ & $\begin{array}{c}\text { Rural } \\
\text { development }\end{array}$ & $\begin{array}{c}\text { Special } \\
\text { area } \\
\text { programmes }\end{array}$ & $\begin{array}{c}\text { Overall } \\
\text { rural } \\
\text { economy }\end{array}$ \\
\hline Annual Plan (1990/91) & 5.8 & 6.8 & 1.5 & 7.1 & 1.7 & $\mathbf{2 2 . 9}$ \\
Annual Plan (1991/92) & 5.9 & 6.5 & 1.5 & 6.4 & 1.6 & $\mathbf{2 1 . 9}$ \\
$\begin{array}{l}\text { 8th Five Year Plan } \\
\text { (1992/93-1996/97) }\end{array}$ & 5.2 & 7.5 & 1.5 & 7.9 & 1.6 & $\mathbf{2 3 . 7}$ \\
$\begin{array}{l}\text { 9th Five Year Plan } \\
\text { (1997/98-2001/02) }\end{array}$ & 4.9 & 6.5 & 1.1 & 8.7 & 0.4 & $\mathbf{2 1 . 6}$ \\
$\begin{array}{l}\text { 10th Five Year Plan } \\
\text { (2002/03-2006/07) }\end{array}$ & 3.9 & 6.8 & NA & 8.0 & 1.4 & $\mathbf{2 0 . 1}$ \\
$\begin{array}{l}\text { 11th Five Year Plan } \\
\text { (2007/08-2011/12) }\end{array}$ & 3.7 & 5.8 & NA & 8.3 & 0.7 & $\mathbf{1 8 . 5}$ \\
\hline
\end{tabular}

Note NA = Not Available

Source Compiled from Gol (2011a).

government in the overall economy. The total magnitude of budgetary expenditure by the government (i.e. combined budgetary expenditure by the Union and State Governments) has shrunk from 27.2 per cent of GDP in 1990/91 to 25.1 per cent of GDP in 2010/11 (GoI 2011b). Over these two decades, there have been a few instances of the total magnitude of budgetary expenditure increasing as a proportion of the GDP; but such developments have happened only temporarily as a result of some sporadic factor (such as a significant hike in salaries of government staff in the late 1990s or the fiscal stimulus package during the global financial crises in 2008/09 and 2009/10). However, on the whole, the trend in the total magnitude of budgetary expenditure by the government as compared to the size of India's economy has been that of stagnation or decline over this period.

Such a scenario of stagnation or decline in the fiscal policy space for the government has led to a gradual withdrawal of state support (i.e.

budgetary support for resources) from a number of sectors. The overall rural economy in general and agriculture in particular have suffered from this development. It manifests in the trends in plan expenditure (that part of budgetary expenditure in India which is meant to address the challenges in socioeconomic development and is supervised by the government organ, the Planning Commission) over the last two decades for agriculture in particular and the overall rural economy in general.

An examination of the trends relating to the share of plan expenditure towards the overall rural economy reveals that this was 23.3 per cent during the 3rd Five Year Plan and it had increased to 25.7 per cent in the 6th Five Year Plan; thus, during the period between the late 1960 s to the mid-1980s, almost a quarter of total plan expenditures were directed towards the overall rural economy (Jha and Acharya 2012). However, in subsequent decades, this share has declined consistently since the 8th Five Year Plan. During the 8th Five Year Plan, this share was 23.7 per cent; in the 11 th Five Year Plan, it had fallen to 18.5 per cent (Table 3), which is the lowest share of plan expenditure towards the overall rural economy since the 1960s.

While the overall priority for plan expenditure on the rural economy has been reduced over the last three Five Year Plans, its implications would have been diverse across the different states due to the varying capacity of the State Governments to step up their non-plan expenditures on the rural economy (i.e. those budgetary expenditures on Agriculture and Allied Activities, Irrigation and 


\begin{tabular}{|c|c|c|c|c|c|c|}
\hline Year/State & $2005 / 06$ & $2006 / 07$ & $2007 / 08$ & $2008 / 09$ & $2009 / 10$ & $\begin{array}{c}\text { Average annual } \\
\text { share }(2005 / 06- \\
2009 / 10)\end{array}$ \\
\hline Assam & 2.36 & 2.78 & 3.13 & 3.29 & 3.85 & 3.08 \\
\hline Bihar & 4.11 & 4.90 & 4.99 & 4.93 & 4.70 & 4.73 \\
\hline Chhattisgarh & 4.53 & 3.93 & 5.09 & 4.81 & 5.29 & 4.73 \\
\hline Jharkhand & 3.48 & 2.98 & 3.36 & 2.84 & 2.54 & 3.04 \\
\hline Orissa & 2.35 & 2.57 & 3.22 & 4.13 & 4.03 & 3.26 \\
\hline Uttar Pradesh & 4.18 & 2.82 & 3.48 & 4.11 & 3.98 & 3.71 \\
\hline West Bengal & 1.35 & 1.24 & 1.42 & 1.32 & 1.58 & 1.38 \\
\hline All states and UTs & 4.92 & 5.39 & 5.31 & 7.28 & 6.01 & 5.78 \\
\hline
\end{tabular}

Note Net State Domestic Product of respective states are at factor costs and at current prices.

Source Computed from data in Reserve Bank of India (2011) and Comptroller \& Auditor General of India (various years).

Flood Control, Village and Small Industries, and Rural Development which are outside the purview of the Planning Commission of India) as well as the varying needs for budgetary support for agriculture and allied sectors across the states.

As regards the selected eastern region states in the country, it is well acknowledged that their fiscal health has been much worse than that of most of the other states since the late 1990s. While a few of these eastern region states have shown a surplus in their state budgets in some of the years since 2007/08, it does not indicate any significant improvement in their capacity to step up budgetary expenditure. Indeed, several of these states have resorted to compression of their budgetary expenditure in order to 'earn' the incentives for 'fiscal consolidation' recommended by the Twelfth Finance Commission of India (whose recommendations were applicable for the five-year period from 2005/06 to 2009/10).

Moreover, the need for budgetary support for agriculture and allied sectors would obviously have been greater in the eastern region states as compared to the other states with similar levels of dependence on agriculture.

Table 4 compares the magnitude of budgetary expenditure on the rural economy (as a proportion of the Net State Domestic Product, or NSDP) in the selected states with the average figure for all states during the period 2005/06-2009/10 (the latest year for which the relevant data are available is 2009/10). It shows that budgetary expenditure on the overall rural economy (as a proportion of the NSDP) in each of the selected states (Assam, Bihar, Chhattisgarh, Jharkhand, Orissa, Uttar Pradesh and West Bengal) has been much lower than the average figure for all states over the period 2005/06-2009/10.

While the Union Government has finally acknowledged the need for stepping up budgetary support for agriculture in the eastern region states, its programme to this end has received little priority in the Union budgets of the last three years. An allocation of Rs 400 crore was provisioned in the Union budget for 2010/11, for the first time for extending the 'Green Revolution' to the eastern region of the country, comprising six states and the eastern part of Uttar Pradesh. The programme aims to improve the rice-based cropping system of Assam, West Bengal, Orissa, Bihar, Jharkhand, Chhattisgarh and eastern Uttar Pradesh. The Union Government intended to provide high-yield seed varieties, technology and irrigation facilities and so on (as essential elements of the Green Revolution) to the farmers; however, the allocation per farmer household in the target region was found to be a meagre Rs 123 per annum. In the Union budget for 2011/12, only Rs 400 crore was again allocated to this programme. The Union Finance Minister has announced in his budget speech for 2012/13 that the allocation towards 


Table 5 Priority for the Department for Land Resources in the Union budget
\begin{tabular}{lccccccc}
\hline Years & $\mathbf{2 0 0 6 / 0 7}$ & $\mathbf{2 0 0 7 / 0 8}$ & $\mathbf{2 0 0 8 / 0 9}$ & $\mathbf{2 0 0 9 / 1 0}$ & $\mathbf{2 0 1 0 / 1 1}$ & $\mathbf{2 0 1 1 / 1 2}$ (RE) & $\mathbf{2 0 1 2 / 1 3}$ (BE) \\
\hline $\begin{array}{l}\text { Total expenditure } \\
\text { under Department of } \\
\text { Land Resources } \\
\text { (in Rs crore) }\end{array}$ & 1,411 & 1,406 & 1,793 & 2,025 & 2,618 & 2,432 & 3,208 \\
$\begin{array}{l}\text { As \% of total Union } \\
\text { Government } \\
\text { expenditure }\end{array}$ & 0.24 & 0.20 & 0.20 & 0.20 & 0.22 & 0.18 & 0.22 \\
$\begin{array}{l}\text { As \% of GDP at } \\
\text { market prices }\end{array}$ & 0.03 & 0.03 & 0.03 & 0.03 & 0.03 & 0.03 & 0.03 \\
\hline
\end{tabular}

Notes RE - Revised Estimate; BE - Budget Estimate; for 2012/13, GDP is as projected by the Ministry of Finance, Gol. Source Compiled from Gol, Ministry of Finance (various years).

bringing the Green Revolution to the eastern region of India has been increased to Rs 1,000 crore. Even this increase might be far from sufficient to address the problems in agriculture confronted by the eastern region states.

The Union Government needs to recognise the need to redesign the policy framework and provide adequate budgetary support for agricultural activities in dryland/rainfed areas in the eastern region states. In fact, agricultural activities in rainfed areas are critical to the performance of the agriculture sector of the entire country since nearly two-thirds of cultivated land in the country is rainfed. Rainfed agriculture also provides a wide range of livelihood opportunities to millions of livestockdependent households, populations living in hilly and difficult terrains, forest dwellers and so on.

Hence, there is an acute need to address some of the core concerns of such agricultural practices. It is crucial to significantly step up the budgetary support for agriculture and allied sectors in the country and accord much higher priority to rainfed agriculture within overall budgetary expenditure on the agriculture sector.

In this context, the budgetary outlays for the Department for Land Resources of the Union Ministry of Rural Development could also be looked at. The Department for Land Resources is meant primarily for development of land resources in the country; it implements all such programmes that are meant for dryland/rainfed agriculture. Table 5 depicts the priority accorded to the Department for Land Resources in the Union budgets of the last seven years.
The total allocation in the Union budget for the special land development programmes (under the Department for Land Resources) constitutes a meagre amount both as a share of the total Union budget as well as of the GDP of the country. For instance, its share in the Union budget was just 0.24 per cent in $2006 / 07$, and this has declined to 0.22 per cent in $2012 / 13$ (BE).

The reason for such a paltry allocation in the Union budget for the Department for Land Resources is that there is no comprehensive programme/scheme in the country to address the concerns of dryland/rainfed agriculture; what exists are a few ad hoc interventions with meagre budgetary support. The Integrated Watershed Management Programme (IWMP) can be considered as the main intervention by the Union Government for providing budgetary support for agricultural activities in dryland/rainfed areas. Analysis of the Union budget allocations/ expenditures towards the IWMP reveals that, in $2007 / 08$, the total amount allocated for the programme was Rs 1,054 crore; the allocation for this programme has been increased to Rs 3,050 crore in 2012/13. However, the level of budgetary support needed for agricultural activities in the rainfed agriculture areas in the country is believed to be much higher than this.

\section{Concluding remarks}

As discussed above, the performance of India's agriculture sector has been a matter of serious concern in recent years. One of the important reasons for the slowdown of growth in this sector seems to have been the stagnation in public expenditure for the overall rural economy (which 
would include Agriculture and Allied Activities, Irrigation and Flood Control, Village and Small Industries, Rural Development and Special Area Programmes) since the early 1990s.

However, the implications of the fall in the priority given to plan expenditure on the rural economy over the last three Five Year Plans would have been diverse across the different states due to the varying capacity of the State Governments to step up their non-plan expenditures on the rural economy as well as the varying needs for budgetary support for agriculture and allied sectors across the states.

While the Union Government has finally acknowledged (since 2010/11) the need to step up budgetary support for agriculture in the eastern region states, its programme for this purpose has received little priority in the last three Union budgets. The Union Government needs to recognise the need to redesign the policy framework and provide adequate budgetary support for agricultural activities in dryland/rainfed areas in the eastern region states.

The government needs to pursue a more progressive fiscal policy in general, which would expand the scope for public expenditure in the economy; and it needs to significantly step up the

\section{References}

Amin, Samir (2004) 'The Geopolitics of Contemporary Imperialism', paper presented at The Economics of the New Imperialism conference, Jawaharlal Nehru University, New Delhi, 22-24 January, www.networkideas.org/ feathm/feb2004/Samir_Amin_Paper2.pdf (accessed 7 March 2012)

Bates, R. (1997) 'Institutions as Investments', Journal of African Economies 6.3: 272-87

Bhalla, G.S. (2007) Indian Agriculture Since Independence, New Delhi: National Book Trust

Chand, Ramesh (2010) 'SAARG Agricultural Vision 2020', Agricultural Economics Research Review 23: 197-208

Comptroller \& Auditor General of India (various years) Combined Finance and Revenue Accounts of Union and State Governments, New Delhi: Government of India

Fan, S.; Hazel, P. and Haque, F. (2000) 'Targeting Public Investments by Agroecological Zone to Achieve Growth and Poverty Alleviation Goals in Rural India', Food Policy 25.4: 411-28 priority given to agriculture in its fiscal policy. Given the strong linkages between the core agriculture sector and other areas of the rural economy, the thrust in the fiscal policy should be on comprehensive rural development, which could also enable a much stronger revival of the agriculture sector. Also, while the government needs to significantly step up budgetary support for agriculture and allied sectors in the country, much higher priority within this needs to be accorded to rainfed agriculture.

Since almost two-thirds of cultivated land in the country is under dryland/rainfed agriculture, the practices of rainfed agriculture require much greater state support in terms of policies and public resources. Instead of indiscriminately extending the agricultural policies and practices of the Green Revolution to rainfed areas, the government should try to put in place appropriate public support systems, institutional mechanisms and technology options for sustainable development of agriculture in these areas. Revitalising agriculture in the eastern region states requires the evolution of a relevant public support system that can address the specific requirements of the concerned states rather than be a mere extension of the practices of irrigated agriculture.

Ghosh, Jayati (2010) 'The Political Economy of Hunger in 21 st Century India', Economic and Political Weekly 45.44: 33-8

GoI (Government of India) (2012) Economic Survey 2011/12, New Delhi: Oxford University Press

GoI (Government of India) (2011a) Economic Survey 2010/11, New Delhi: Oxford University Press

GoI (Government of India) (2011b) Indian Public Finance Statistics 2010/11, New Delhi: Ministry of Finance

GoI (Government of India) (2011c) Agricultural Statistics at a Glance 2011, New Delhi: Ministry of Agriculture, Department of Agriculture and Cooperation

GoI (Government of India) (various years) Union Budget, New Delhi: Ministry of Finance

Hayami, Y. and Ruttan, V. (1985) Agricultural Development: An International Perspective, Baltimore MD: Johns Hopkins University Press

Jha, Praveen (ed.) (2011) Progressive Fiscal Policy in India, New Delhi: Sage Publications 
Jha, Praveen (2002) Land Reforms in India - Issues of Equity in Rural Madhya Pradesh, New Delhi: Sage Publications

Jha, Praveen and Acharya, Nilachala (2012) 'Expenditure on the Rural Economy in India's Budget since the 1950s: An Assessment', Review of Agrarian Studies 1.2, http://ras.org.in/ index.php?citation=expenditure_on_the rural_economy_in_indias_budgets_since_the 1950s (accessed 23 March 2012)

Patnaik, Prabhat (2005) 'The Crisis in India's Countryside', paper presented at the India: Implementing Pluralism and Democracy seminar, Department of Philosophy, University of Chicago, 11-13 November

Patnaik, Utsa (2011) 'Unbalanced Growth, Tertiarization of the Indian Economy and Implications for Mass Living Standards', in Praveen Jha (ed.), Towards Progressive Fiscal Policy in India, New Delhi: Sage Publications

Patnaik, Utsa (2007) 'Neoliberalism and Rural Poverty in India', Economic and Political Weekly 42.30: 3132-50

Patnaik, Utsa (2006) 'Poverty and NeoLiberalism in India', Rao Bahadur Kale Memorial Lecture delivered at Gokhale Institute of Politics and Economics, Pune, www.networkideas.org/featart/jan2007/neoliberalism.pdf (accessed 7 March 2012)

Patnaik, Utsa (2003) 'Deflation and Déjà vu: Indian Agriculture in the World Economy', in V.K. Ramachandran and M. Swaminathan (eds), Agrarian Studies: Essays on Agrarian
Relations in Less Developed Countries, New Delhi: Tulika Books

Pinstrup-Andersen, P.; Londono, N. and Hoover, E. (1976) 'The Impact of Increasing Food Supply on Human Nutrition: Implications for Commodity Priorities in Agricultural Research and Policy', American Journal of Agricultural Economics 58.2: 133-42

Ramachandran, V.K. and Swaminathan, Madhura (2003) 'Introduction', in V.K. Ramachandran and M. Swaminathan (eds), Agrarian Studies: Essays on Agrarian Relations in Less Developed Countries, New Delhi: Tulika Books

Ramachandran, V.K. and Swaminathan, Madhura (2002) 'Rural Banking and Landless Labour Households: Institutional Reform and Rural Credit Markets in India', Journal of Agrarian Change 2.4: 502-44

Reserve Bank of India (2011) Handbook of Statistics on Indian Economy, Mumbai: RBI Sen, Abhijit (2003) 'Globalization, Growth and Inequality in South Asia: The Evidence from Rural India', in Jayati Ghosh and C.P. Chandrasekhar (eds), Work and Well-Being in the Age of Finance, New Delhi: Tulika Books Vyas, V.S. (2008) India's Agrarian Structure, Economic Policy and Sustainable Development -Variations on a Theme, New Delhi: Academic Foundation

Vyas, V.S. (2004) 'Agrarian Distress: Strategies to Protect Vulnerable Sections', Economic and Political Weekly 39.52: 5576-81 